\title{
A Piece about Mother and Fatherland (Utwór o Matce i Ojczyźnie)
}

Author: Bożena Keff (Umińska-Keff)

First Published: 2008

Translations: German (Ein Stück über Mutter und Vaterland, 2010); Italian (Madre, Patria, 2011); French (De la mère et de la patrie, 2017); English (On Mother and Fatherland, 2017).

Theatre Adaptations: Teatr Miejski, Gdynia (2010); Teatr Polski, Wrocław (2011).

About the Author: Born in Warsaw in 1948, Bożena Umińska-Keff is a poet, publicist, film critic, and essayist who publishes her literary works under the name Bożena Keff. She holds a PhD in Polish literature from the University of Warsaw where she is currently a lecturer in the Department of Gender Studies. Her essays and polemical articles have been published in literary journals and newspapers, including Res Publica Nova, Gazeta Wyborcza, Twórczość, Kresy, Midrasz, and Zadra. Umińska-Keff creates narratives based on a combination of oneiric motifs and sharply sketched depictions derived from social and historical contexts (Dąbrowska, 2008). Her poetic style might be defined as lyrical-philosophical wandering in time (Maliszewski, 2006) by which the writer attempts to identify herself with her feminine and masculine characters. In 2013, Umińska-Keff published another collection of essays with the title Antisemitism: Unclosed History (Antysemityzm. Niezamknięta historia), which is meant as a sort of textbook for students.

Further Important Publications: Razem osobno (Together in Separation, 1986; poetry); Sen o znaczeniu snów (A Dream about the Meaning of Dreams, 1994; poetry); Nie jest gotowy (He Is Not Ready, 2000; poetry).

\section{Content and Interpretation}

Considered an interesting mosaic of opera, tragedy and oratorio (Czapliński, 2008), $A$ Piece about Mother and Fatherland (also translated as On Mother and Fatherland) is striking for its extraordinary formal aspects, which Umińska-Keff draws in part from Menippean satire. The work brings together a host of mutually conflicted voices, tones, and styles: the weeping and gnashing of teeth in the biblical prophecies of Jeremiah, for example, persecuted by his own ministry, can be heard in the mother's lamentation over her individual suffering. Where Jeremiah proclaims, "Oh, my anguish, my anguish! I writhe in pain. Oh, the agony of my heart” (4:19), the words from The Song of Meter (Pieśn Meter) echo: "I am sitting here alone in four walls in four walls alone” (Keff, 2008, p. 14). Juxtaposed to intertextual motifs evoking the canon, A Piece about Mother and Fatherland features numerous references to everyday life in contem-

Ә Open Access. () 2021 Anna Maria Skibska, published by De Gruyter. (cc)BY-NC-ND This work is licensed under a Creative Commons Attribution-NonCommercial-NoDerivatives 4.0 License. https://doi.org/10.1515/9783110671056-078 
porary Poland, highlighting the internal conditions of "cultural polarisation". Drawing from her mixed Polish and Jewish background (as reflected in the two parts of her hyphenated surname), Umińska-Keff suggests that issues of cultural heritage and cultural memory are essentially different from those faced by her narrator, in the figure of the adult daughter Usia, characterised instead by a kind of "identity-in-progress".

A Piece about Mother and Fatherland consists of eight parts, starting with a prologue dominated by the mother's terrifying monologue, and ending with a grotesque epilogue entitled “A Song From the Medical Clinic" (reminiscent of a songbook). Written in italics, the initial monologue illustrates how the Holocaust continues to haunt the mother's dreams, where she finds herself on a railway platform, pressing a mysterious bundle to her chest. What she discovers inside the bundle, however, is not an infant child, but a screaming hairy mass of lint and blood. The life of this thing demands its protection, with a burning stench and scream of terror. It is worth considering the mother's reflection: "I thought I would only hold on to it for a while / but now I can see, no one will take it from me" (p. 5). The enigmatic contents of the bundle serve as an apt symbol both of the Jewish fate and of a burden deposited in the past that continues to weigh on the future, in this case the future of the narrator Usia.

Umińska-Keff's mother is a Polish Jew and the only member of her family to survive the Holocaust. In this way she appears at the convergence of two tragedies, one concerning her personal history and the other her nation's. Preoccupied with the theme of the extermination of Jews, the character of the mother dominates the text. Standing in for the homeland itself, she considers herself above all criticism, demanding absolute respect and deference to authority. As a consequence, the daughter's efforts to describe her mother put her in a precarious position, stylistically represented by the multiplication of literary forms and historical references. References to the theatre of Greek antiquity, for example, suggest that the mother's complaint both transcends time and is located in a specific historical context. She preaches endlessly about "the history of her history during the war" and "the Jewish fall to the subhuman” (p. 9). Another important point of reference is Maus by Art Spiegelman. Inspired by Spiegelman's experiments with form, Umińska-Keff assigns all responsibility for the narrative to the figure of the daughter, in this way illustrating the mechanisms of "postmemory". Taking these formal aspects of the work into consideration, Maria Janion and Izabela Filipiak propose reading it through the structure of oratorio, recalling the motifs that characterise the ancient Greek goddesses Demeter, Persephone, and Hecate. Deprived of her own identity, the daughter is reduced to the sense of hearing. Because she is expected to do nothing but listen to her mother's stories of trauma and survival - experiences she is unable to face - the daughter has no way of playing the role of partner in any real dialogue. As the mother herself points out, "If your life were as tragic as mine was / sometimes I could speak with you as with someone / who has a legitimate existence” (p. 58). After suggesting that Usia stops reacting to her narrative, she starts threatening her with suicide, and composes crude scenes in front of her daughter. The mother continuously exalts herself through her suffering, revealing 
her messianic attitude - an attitude founded on her guilt towards those who died (as she confesses abandoning her mother to save herself), and giving her privileges vis$\grave{a}$-vis the dead from which her daughter is excluded.

\section{Main Topics and Problems}

Themes that determine the central issue of this work are a derivative of the worldview of the daughter, who dares to describe her titular relationship with her mother and fatherland as one that is toxic and oppressive to her identity and personality. In the struggle with her mother and their common homeland, the narrator can do nothing more than become a victim whose existence is controlled by the conditions imposed by the titular forces at work in the story. Umińska-Keff's work engages with difficult dichotomies that cause the reader to lose their bearing, while the postmemory narration serves ambiguously as both positive and negative transgression of the established Holocaust experience. In the final analysis, the patriarchal mother figure in rivalry with her daughter is not so different from the Oedipus complex in its classical, Freudian formulation, so that it gives the narrative an almost cannibalistic character. Moreover, its multilayered structure of canonical genres in collision with various manifestations of contemporary popular culture results in a trivialisation of ancient myths and literary cultures while at the same time attesting to their ongoing life and relevance.

Umińska-Keff's wide-ranging experiments with style allow her to combine elements of high and low culture, most notably, perhaps, with regard to such recognizable products of commercial cinema as Alien, Lara Croft, and Nosferatu. The titular alien that hides among the crew of the Nostromo, for example, is identified by the narrator as her mother (“Alien Meter"), while she identifies with the character of Ripley. This image of the mother as an alien parasite nestling inside Ripley-Usia speaks above all to the mother's need for the daughter's body in order to survive - a motif that entails the obsessive exploration of bodily topics and animal aspects of human life.

The figure of the Holy Mother who can be easily replaced by the Fatherland highlights another important topic, and leads to the question whether it is a civic duty to lament over the torment experience by both of them. Claiming to be an atheist, the mother like the daughter weakens her ties with Poland, and in this way with a community typically defined by religion. Usia's atheistic attitude seems more unshakable than her mother's, since the latter is devoted in her way to the cult of the Holocaust, and demands that it be considered as a living relic. Usia ultimately frees herself from her mother's narrative, yet she finds herself unable to deal with concepts and formulas generated by the Fatherland - especially with its national myths.

\section{Cited Works}

Czapliński, P. (2008), Mauzoleum. Tygodnik Powszechny, 37. Available at: https:// www.tygodnikpowszechny.pl/...583 [Accessed: 28.10.2020]. Dąbrowska, K. (2008), Bożena Umińska (Keff). Życie i twórczość. Artysta. Culture.pl Available at: https://cul- 
ture.pl/pl/tworca/bozena-uminska-keff [Accessed: 05.10.2019]. Janion, M., Filipiak, I. (2008). Zmagania z matką i ojczyzną. In: B. Keff, Utwór o matce i ojczyźnie, pp. 8198. Keff, B. (2008). Utwór o matce i ojczyźnie. Kraków: Korporacja Ha!art. Maliszewski, K. (2006). Między snem a jawą. In: K. Maliszewski, Rozproszone głosy. Notatki krytyka. Warszawa: Prószyński i S-ka.

\section{Further References}

Hirsch, M. (2012). The Generation of Postmemory: Writing and Visual Culture After the Holocaust. New York: Columbia University Press. Lachmann, R. (1990). Mnemotechnik und Simulakrum. In: R. Lachmann, Gedächtnis und Literatur. Frankfurt a.M. Suhrkamp, pp. 13-50. Lachmann, R. (2009). Mnemotechnika i symulakrum. In: M. Saryusz-Wolska, ed., Pamięć zbiorowa i kulturowa. Współczesna perspektywa niemiecka. Kraków: Universitas. Mach, A. (2016). Świadkowie świadectw. Postpamięć zagłady w polskiej literaturze najnowszej. Torun: Wydawnictwo UMK.

AMS 